\title{
DOM LUÍS DE FRANÇA: A ALIANÇA SIMBÓLICA ENTRE PARÁ E MARANHÃO
}

Dom Luis King of France: The Symbolic Alliance between Pará and Maranhão

Taissa Tavernard de Luca ${ }^{1}$

UEPA - Pará/ Brasil

RESUMO: Este trabalho tem por objetivo analisar o panteão da Mina em Belém do Pará enfocando uma categoria de entidades de alto status, denominada de "senhores de toalha" ou "nobres gentis nagôs". Trata-se de reis e nobres europeus que possuem ligação com a história luso-brasileira e que foram "divinizados". Eles pertencem a várias nacionalidades e são divididos por mim em duas categorias: realeza lusitana e reis estrangeiros. Dentre eles abordarei a trajetória de Dom Luís, um personagem híbrido construído a partir da história de vida dos muitos reis de Nome Luís que estiveram a frente do Trono francês. Recupero parte da história de vida desse personagem na tentativa de entender o processo de divinização do (s) homem (s) público (s) bem como a construção dos mitos ligados a ele (s). Procuro apontar valores que estão subjacentes as narrativas míticas, dentre os quais destaco o simbolismo da sociedade de corte.

Palavras-chave: História; Mito; Religião de Matriz Africana; Tambor de Mina

ABSTRACT: This work aims to analyze the Pantheon of the Mine in Belém do Pará focusing on a category of entities of high status, called "towel gentlemen" or "nobres gentis nagôs". These are European kings and nobles who have links with Luso-Brazilian history and who have been "deified". They belong to various nationalities and are divided by me into two categories: Portuguese royalty and foreign kings. Among them I will address the trajectory of Dom Luís, a hybrid character built from the life story of the many kings of Nome Luis who were in front of the French Throne. I recover part of the life story of this character in an attempt to understand the process of divinization of the public man (s) as well as the construction of the myths connected to him (s). I try to point out values that underlie the mythical narratives, among which I emphasize the symbolism of the court society.

Keywords: History; Myty; African Religion; Tambor de Mina.

\footnotetext{
1 Doutora em Antropologia pela Universidade Federal do Pará, Professora Adjunta 1 do Programa de Pós-Graduação em Ciências da Religião da Universidade do Estado do Pará e Coordenadora Do Grupo de Pesquisa Religiões de Matriz Africana na Amazônia. taissaluca@gmail.com.
} 


\section{Introdução}

Algumas pessoas pensam as religiões afro-brasileiras como uma forma homogênea de devoção a entidades negras. Falar em religião negra é falar em diversidade de matrizes que podem ser exemplificadas como Candomblé ${ }^{1}$, Mina ${ }^{2}$, Umbanda ${ }^{3}$, Xangô ${ }^{4}$, Jurema ${ }^{5}$ povoam os centros urbanos brasileiros apresentando, ritmos, danças, rituais e divindades diferentes.

A religião que vou abordar neste trabalho é especificamente a Mina ou Tambor de Mina; a mais antiga e tradicional, radicada em território Amazônico no final do século XVII. Religiosidade oriunda da costa ocidental da África, mais especificamente, do antigo reino do Daomé outrora situado no atual território do Benim. Esta vertente de culto se estabeleceu no eixo norte e nordeste, mais especificamente no estado Maranhão de onde migrou para o Pará provavelmente no período da economia gomífera.

O que mais interessa mencionar nos limites deste artigo, sobre essa religião é que seu panteão é formado por diversas categorias de entidade reproduzindo a fábula das três raças (Da Matta,1991), mito fundante do povo brasileiro. É possível verificar entidades negras, indígenas e os brancas.

Para falar do conjunto de entidades que compões o panteão da Mina no Pará, recuperarei Anaíza Vergolino quando diz que em se tratando da Mina no Pará; "tanto se cultua os orixás nagôs (...) quanto aos voduns jêjes que podem corresponder aos orixás nagôs (...). De todos os orixás, Iansã é sem dúvida o mais popular (...). Em Belém é amplamente conhecida como Babassueira, Maria Bárbara Soeira ou simplesmente Maria Bárbara.” (Vergolino, 2003: 22).

Esmiuçando essa idéia, o panteão se divide em duas categorias: as divindades e os encantados.

As divindades são tanto os orixás - panteão yorubano - quanto os voduns -panteão jeje - (Leacocks, 1972) que ou representam as forças da natureza, ou são ancestrais negros divinizados. Esta união de forças da natureza e negritude na mesma categoria suscita análise acerca da interpretação da figura do negro, na sociedade brasileira. São eles as entidades máximas no que tange a hierarquia do panteão.

\footnotetext{
${ }^{1}$ Chama-se de "Candomblé" ao culto de Nação "Iorubá" cuja características principais são a adoração aos "Orixás" e o processo iniciático de 21 dias.

${ }^{2}$ Ver referência abaixo.

${ }^{3}$ Religião fundada no Brasil a partir de crenças e ritos oriundos do catolicismo, do espiritismo Kardecista e dos cultos de matiz africana.

${ }^{4}$ Denominação dada ao culto "iorubá” no Recife.

${ }^{5}$ Religião afro-indígena do nordeste que cultua os mestres e faz uso de uma bebida litúrgica de mesmo nome. REVISTA RELEGENS THRÉSKEIA - 2018 - UFPR - UEPA
} 
Por isso são comumente referidos pela expressão: Os "brancos". Por vezes orixás e voduns são descritos como categorias sinônimas, outras vezes são diferenciadas, embora toda vez que se pergunte quem é um vodum - a exemplo de Dan - eles sempre explicam a partir da mitologia yorubana - no caso Oxumaré. No Pará a mitologia jeje é muito pouco lembrada. Neste sentido ela se recria a partir do referencial dos orixás. Essas entidades são organizadas em famílias africanas, geralmente festejados no dia do santo católico (Ferretti, M, 2000, 2003).

Os encantados são, por sua vez, entidades não africanas (Ferretti, M, 2000) que pertencem a diversas nacionalidades, são europeus, turcos, índios, brasileiros, etc. Sua característica maior é a não morte (Ferretti, M 2000; Vergolino, 2003; Prandi \& Souza, 2001; Shapanan, 2001). A maioria dos encantados, são descritos como seres (pessoas, bichos) que tiveram vida, mas que não passaram pela experiência da morte. Saíram desse mundo de forma fantástica (Todorov, 2003) e passaram a habitar as encantarias que se localizam em lugares geográficos específicos, como matas, rios, praias, formações rochosas etc...

Seth e Ruth Leacock dão a seguinte definição:

\begin{abstract}
"Litterally this term can be trastated as "enchanted one" but since this term in english suggest creatures held in some sort of temporary magic spell that might be broken the translation inappropriate. While it is true that some encantados are concived of former men and women, it is believed that their natural destiny was somehow permanently altered and that under no circumstances will they ever revert to the condition. Besides many encantades were born as such and never lived or earth as mortal and the origin of a still other is quite unknown (...) cult members point out are mistery that human cannot understand" (Leacocks, 1972).
\end{abstract}

Essa categoria pode ainda ser subdividida em encantados que se aproximam dos voduns e encantados caboclos. Os primeiros são chamados nobres gentis nagôs ${ }^{6}$ ou senhores de toalha ${ }^{7}$, e correspondem à nobreza européia de países católicos. Os mais comuns são os nobres portugueses que, de alguma forma tiveram relação com o processo de expansão marítima e colonização do Brasil.

\footnotetext{
${ }^{6}$ Chama-se de nobres gentis nagôs ou senhores de toalha aos encantados de status superior que representa a nobreza européia.

${ }^{7}$ Existem outras denominações que se referem a essas entidades quais sejam; os brancos ou gente fina, esta última já registrada pelos Leacock (1972) durante a década de cinqüenta.

REVISTA RELEGENS THRÉSKEIA - 2018 - UFPR - UEPA
} 
Essas entidades são todas nobres, em sua maioria reis. Em vidas foram detentores do poder absoluto, centralizador, expansionista. Talvez esse seja o elemento que os tenha tornado sagrados a ponto de serem relacionados às divindades africanas ${ }^{i}$. Foram divinizados os membros das dinastias de Avis e Borgonha numa referência clara ao expansionismo e à colonização do portuguesa. Neste sentido, considerando que, no período histórico referido o Brasil era apenas colônia de Portugal, a mitologia fala de nacionalismo. Não há referência nenhuma ao processo de independência do Brasil. Um informante sugeriu o encantamento de D. Pedro e ainda assim o descreveu como um encantado sem status, comum na linha de cura, onde baixa despido de nobreza.

Geralmente são apenas equiparados aos voduns e orixás, por vezes até classificados desta forma ou incorporados à suas famílias. Todos os nobres gentis nagôs são descritos como "brancos" e formam, junto com os voduns e orixás o patamar mais alto da hierarquia mineira. Organizados em famílias ${ }^{8}$, eles tematizam, cada um ao seu modo, valores como o cristianismo, lusitanismo, absolutismo, poder centralizado, etc...

Os antropólogos Seth e Ruth Leacock classificam as três entidades supra citadas; voduns, orixás e senhores de toalha dentro da categoria senhores que eles descrevem como possuidores de "high status". Esse grupo pode ser subdividido segundo o gênero em "Male" (masculino) e "Female" (feminino). Neste sentido temos o grupo masculino, segundo eles, composto por Oxalá, 'Xangô' (José Tupinambá), D. Luiz, Rei Toi Adossu, Akossi Sapata, Bem Boçu da Cana Verde, Rei de Nagô, Rei Noé, Rei Salomão, Rei Taculumi, Urubatan Jesus. O feminino, muito menos denso, compõe-se de Nana Burucô, Rainha Barba (Inhançã), Iemanjá, Janaina, Oxum, Princesa Sinhá Bê (Leacock, 1972: 157).

Os caboclos são entidades mestiças de várias nacionalidades. "São encantados, não são espíritos de índios mortos" (Vergolino, 2003: 22), nem tampouco são todos índios. Existem várias famílias de cabocos como os codoenses $^{9}$, os juremeiros ${ }^{10}$, os surrupiras $^{11}$,

\footnotetext{
${ }^{8}$ Seth e Ruth Leacock (1972) informam a existência de certos encantados que “vivem sozinhos sem parentes” (tradução nossa). Eles denominaram essas entidades de "solitary spirits".

${ }^{9}$ Recebem o nome de codoenses os cabocos classificados como negros, de hierarquia mais "terra a terra". Sua encantaria está localizada nas matas da cidade de Codó, situada no Maranhão. Pela sua baixa posição na hierarquia do panteão, quando incorporados em seus filhos, efetuam trabalhos domésticos.

${ }^{10}$ São cabocos índios, moram em tribos. Sua encantaria está situada na mata da Jurema, um lugar mítico. São descritos como valentes e guerreiros. Alguns possuem nomes de índios da literatura brasileira, como Iracema.

${ }^{11}$ Cabocos ora descritos como índios não civilizados, ora como seres antropomorfos muito peludos. O fato é que os surrupiras são entidades arredias com hábitos selvagens. Costumam subir em árvores espinhosas e se embrenhar no meio da mata.

REVISTA RELEGENS THRÉSKEIA - 2018 - UFPR - UEPA
} 
os $\operatorname{urcos}^{12}$ (ou mouros $^{13}$ ) e os bandeirantes ${ }^{14}$ (Ferretti, M, 2000; Vergolino, 2003; Prandi \& Souza, 2001) que possuem status bem inferior do que os encantados descritos acima ${ }^{15}$.

Apesar dessa riqueza simbólica que suscita muitas possibilidades de análise, abordarei, nesta sessão apenas o personagem branco do panteão, com o destaque a categoria denominada Nobres Gentis Nagôs ou Senhores de Toalha. Mais especificamente darei espaço aos personagens mitológicos não portugueses que ganham destaque no panteão do Tambor de Mina.

As dinastias estrangeiras: uma ameaça eminente à soberania nacional portuguesa

Existem algumas dinastias não portuguesas no panteão da mina. Um exemplo é a Família da Gama, que é espanhola. As entidades dessa família têm o mesmo status das portuguesas, o que é garantido não pelo elemento nacionalismo, mas pelo catolicismo haja vista ser a Espanha um país cristão. Ainda assim posso dizer que estes encantados, são bem menos conhecidos em terras paraenses. Encontrei um informante que recebe Dom Miguel da Gama, o chefe da família.

Outra família de fundamental importância é a francesa. Ao contrário do que acontece com os reis portugueses remete-se a diversos reis da França, concentrados na figura de um único encantado: Dom Luís Rei de França. Este personagem traz características de três monarcas quais sejam: Dom Luís IX - o santo - Dom Luís XIII - o delfim no período da ocupação do Maranhão - e seu filho Dom Luís XIV - o Rei Sol ${ }^{16}$. Além deles outros personagens são citados como Maria Antonieta e Joana D’ Arc. Os demais não são conhecidos pela historiografia.

\footnotetext{
12 Os turcos são os cabocos mais comuns no estado do Pará. Trata-se dos mulçumanos que lutaram contra os cristãos nas célebres cruzadas. Uma herança clara do folclore ibérico, presente em folguedos como a Marujada de Bragança, a Festa de São Thiago, em Mazagão etc. O chefe da família da Turquia é o Rei da Turquia.

${ }^{13}$ Há quem descreva os turcos como brancos, no entanto são os brancos não católicos.

${ }^{14}$ Os bandeirantes são desbravadores ligados ao episódio histórico das Entradas e Bandeiras. Trata-se de uma família eclética, pois inclusiva. Conta-se que seu João da Mata - o chefe da família - em suas conquistas ia agregando os índios, que encontrava pela frente. Outras narrativas afirmam que índios e bandeirantes não se dão bem pelo fato de terem travados diversas guerrilhas com os mesmos.

${ }^{15}$ Seth e Ruth Leacock (1972: 157), alistam os seguintes caboclos:

- Masculinos: Antônio Luís Corre Beirado, Boiadeiro da Visaura, caboclo Brabo, Caboclo Luar, Caboclo de Olha Dagua, Cidalino, Constantino (Bahiano Grande), Seu Gavião, Jurupari, Marabá, Marinheiro, Mestre Marajó, Pombo do Ar, Ricardino, Seu Risca, Tubian. - Femininos: Herondina, Indaê, Iracema, Maria Mineira da Luz, Preta 'mina'.

${ }^{16}$ D. Luís IX é da dinastia Capetiana e os demais - D. Luís XIII e D. Luís XIV - são da casa de Bourbon. REVISTA RELEGENS THRÉSKEIA - 2018 - UFPR - UEPA
} 
Existe uma referência a um Clóvis, descrito como padre que lutou com Rei Sebastião em Alcacer Quibir tendo se agregado a sua família. Interessante destacar que a historiografia destaca Clóvis I como responsável pelo processo de cristianização da França. Neste sentido se o imaginário realizou rearranjos ele o fez em cima de um fundamento comum que torna o mito coerente diante do "projeto" maior que é falar de cristianismo.

O rei francês, também católico, é pouco cultuado no Pará ${ }^{17}$. Fui a uma única festa em homenagem a ele realizada pelo falecido Pai Bené ${ }^{18}$, no dia 25 de agosto de 2007. Nesta ocasião saí um tanto quanto decepcionada uma vez que - apesar da homenagem - nenhuma doutrina do mesmo foi entoada nem tampouco ele se fez presente na forma de transe extático. Apesar das ausências, a figura de Dom Luís estabelece uma ligação simbólica entre Pará e Maranhão estado onde a mina “deita raízes” (Vergolino, 2003).

Vale pensar no porquê o imaginário abriu mais espaço à nobreza francesa. Por que não os ocultou da mesma forma que fez com os espanhóis haja vista que esta nação foi responsável pela ocupação do estado do Maranhão? Partindo também de hipóteses lembro que o domínio francês sobre o Maranhão foi efêmero.

\section{As Várias Faces de um Rei Francês que Migrou para o Maranhão}

Desses senhores de toalha, o menos citado no Pará é sem dúvida Dom Luís. Ao longo de minha estadia em campo não encontrei nenhum filho que o receba e muitas referências a uma única religiosa que o teria feito em terras paraenses: Mãe Maria Aguiar. Esta mãe-de-santo se tornou muito conhecida por ter sido a introdutora da umbanda na capital paraense e por seu estreito laço de amizade com o intendente Magalhães Barata, que segundo "corre a boca miúda", tirava os sapatos e baiava em sua casa de santo.

Desde que mãe Maria Aguiar morreu, em meados da década de setenta, ninguém mais no Pará recebeu o encantado francês. Seth e Ruth Leacock (1972) registraram a presença do D Luís na cabeça da religiosa supracitada e sobre ele comentam:

\footnotetext{
17 Toda vez que questionamos sobre este encantado os informantes são unânimes em afirmar que era recebido por Maria Aguiar, mãede-santo famosa por sua ligação com o intendente Magalhães Barata e por ser responsável pela introdução da umbanda no Pará. Alguns informantes relataram que os maranhenses nunca aceitaram essa ligação entre a paraense acima citada e Dom Luis.

${ }^{18}$ Mineiro com mais de 50 anos de iniciado. Filho-de-santo do maranhense Manuel Colaço Veras, fundador da FEUCABEP

REVISTA RELEGENS THRÉSKEIA - 2018 - UFPR - UEPA
} 


\begin{abstract}
"Dom Luis is intensified as King Louis XVI of France, the king executed during the french revolution. Louis XVI would seen the most unlikely candidate for metamorphosis into an Amazonian supernatural. Unlike the other historicals figures who have been turned into encantados, Louis is neither Portuguese, nor brasilian and although São Luís in Maranhão was founded by the French, there was no lasting imprint of French culture. In addition the character and life story of Louis do not exactly make him the stuff out of with folks herois are molded" (Leacoks, 1972: 159).
\end{abstract}

Esta versão é certamente elaborada por influência de Maria Aguiar que se dizia a reencarnação de Maria Antonieta ${ }^{19}$. Há quem diga que essa religiosa foi muito criticada pelos maranhenses, haja vista que as entidades da linhagem de Dom Luís refletem de uma peculiaridade da história local, daquele estado.

Cultuar Dom Luis Rei de França é falar da identidade maranhense ou atrelar-se a ela. Apesar de o Maranhão significar a Meca da mina no Pará, Dom Luís é lembrado pelos paraenses sem muitas minúcias.

Quem mais me falou sobre ele foi Pai Hermeto Paraense ${ }^{20}$ (mineiro de segunda migração), informando que a entidade era o "patrão de seu pai-de-santo”. Disse que Dom Luís corresponde a São Luís, embora não seja confundido com ele. Trata-se de um rei oriundo da corte francesa que se instalou em São Luís. Sabe que é o senhor do Maranhão, que teve vida e era um menino, conforme mostra a doutrina.

\author{
"Ele é menino \\ Ele é Francês \\ Dom Luís é rei Nagô"
}

De acordo com a sua narrativa, seu ancestral o recebia com muita pompa e altivez. Em sua homenagem fazia-se a festa do Divino Espírito Santo que costumava durar quinze dias. Durante esse período montava-se uma corte no terreiro. Todos os filhos se cotizavam para mandar uma joia ${ }^{21}$ a casa matriz.

\footnotetext{
${ }^{19}$ É importante lembrar que a ideia da reencarnação é uma absorção de um dogma advindo do espiritismo kardecista que muito exerceu influencia sobre a umbanda.

${ }^{20}$ Os nomes dos informantes serão modificados com a finalidade de preservar sua identidade.

${ }^{21}$ Jóia é sinônimo de contribuição financeira.

REVISTA RELEGENS THRÉSKEIA - 2018 - UFPR - UEPA
} 
Pai Hermeto recebe um dos filhos de Dom Luís, Toy Lauro das Mercês, que também foi da corte francesa e já era maduro quando se encantou. Dom Luís teve ainda outro filho, Antônio Luís Corre Beirada, este teria nascido na corte, mas não aceitou a realeza por não gostar de suas regras. Em função disso deixou a casa paterna e foi viver como caboco agregado em outra família.

Uns dizem que ele entrou para a família da Turquia, outros, que anda pelo mundo "correndo beira", ou seja vagando. O fato é que não usa bastão de nobreza. Neste sentido pai Brasil conclui: "uns se misturaram e outros não, uns aceitaram a mistura e outros não" (Pai Hermeto Paraense, Mineiro).

Há quem diga22 que franceses e turcos são inimigos de encantaria. Em vida Dom Luís teria derrotado os infiéis na última batalha que realizou contra os Mouros. Nesta circunstância teria aprisionado os vencidos trazendo-os nos porões de seu navio. Dentre os prisioneiros estava Dona Mariana. O navio francês afundou e, como num passe de mágica, todos se encantaram. Uma vez na encantaria formaram famílias diferentes e continuaram inimigos.

Prandi \& Souza (2001), baseados nas narrativas de um paraense já falecido, radicado em São Paulo - Francelino de Shapanã23 - afirmam que Dom Luís encantou-se com toda a sua corte na baía de São Marcos em São Luís, exatamente entre a praia da Ponta da Areia e a Ilha do Medo.

Sua família é composta por uma irmã - Rainha Rosa - e seus três filhos - Toy Lauro das Mercês, Dom Carlos e Dona Maria Antônia, omitindo, Corre Beirada.

Outro religioso mineiros que fazia referência a Dom Luís era Pai Tangará que reconstrói o mito a partir de pesquisa histórica. Este religioso, assim como os demais acima mencionados, traça uma correlação entre Dom. Luís e o vodum Dadarro quando afirma:

\footnotetext{
22 Versão fornecida por pai Serginho de Oxossi, também membro da segunda geração de mineiros.

${ }^{23}$ Pai Francelino de Shapanan teria sido iniciado em Belém do Pará por Mãe Joana de Shapanan, mas pagou obrigação de 21 anos com pai Jorge de Itacy, em São Luís do Maranhão.

REVISTA RELEGENS THRÉSKEIA - 2018 - UFPR - UEPA
} 


\begin{abstract}
"Dom Luís era o vodum Dadarro, primeiro rei da dinastia de Daomé. Ele tinha como tutela o rei Sol (...). Quando ele Agassou - para nós chamado Agassou - ele veio a terra, ele veio, voltou depois veio de novo e nesse processo ele acaba sendo ligado a família da França, acaba dominando a região do Benim. Ele domina igualmente como os Dahomeanos, eles tinham poder sobre o povo. A ligação entre Agassu, Dadarro e rei Dom Luís é muito forte. A ligação é tanta, que Agassu, que era encantado numa pantera está estampado na antiga bandeira da França". (Pai Tangará, mineiro).
\end{abstract}

Não fica totalmente claro se essa ligação se estabelece por equivalência, processo de reencarnação ou se Agassu e o Rei Sol cultuavam o mesmo vodum: Dadarro conforme a frase: " $O$ vodum cultuado por Agassu era o mesmo do rei sol". Mas Dom Luís aparece associado a um personagem diferente daquele mencionado pelos Leacock (1972). Quem é referido na encantaria agora, é Luís XIV, o Rei Sol. Este soberano francês teria se encantado numa tentativa de poder regressar e continuar o seu reinado.

Diferentemente da versão de pai Hermeto, para Tangará:

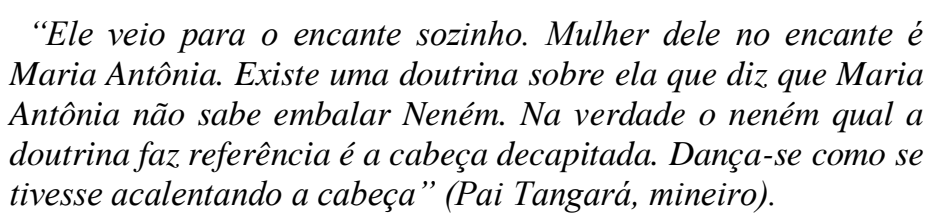

Os mineiros descendentes da casa de Pai Jorge de Itacy, informam que Maria Antônia seria uma filha de Rei Dom Luís e esvaziam a correlação com Maria Antonieta. Tangará reitera que a França antes da cristianização era um lugar mágico. Os nobres acostumavam fazer sacrifícios humanos e degolavam meninos de cinco anos cuja cabeça era colocada sobre uma bandeja de prata e ainda assim continuava falando. Afirma que as catedrais francesas foram construídas em espaços estratégicos, portais de encantaria.

Outros personagens franceses são lembrados embora tenham se agregado em categorias de entidade de menor status. Dentre eles citamos o célebre Tranca Rua que aparece na narrativa deste religioso como um nobre francês que teria organizado a matança de São Bartolomeu e por isso passara a ser festejado em 24 de agosto. Este personagem teria ficado preso no emaranhado do sangue dos inocentes que ele matou e se transformado em um Exu.

Outra figura histórica a ser lembrada é Joana D’ Arc, branca francesa, aloirada que teria se juntado aos turcos. O elemento que liga Joana D'Arc aos mouros é a perseguição religiosa, haja vista que Joana D’ Arc fora queimada pelos tribunais da inquisição.

Se até agora descobri analogias entre Dom Luís - encantado - Dom Luís IV e Dom Luís VI, é preciso lembrar que dois outros monarcas franceses podem ainda ser incorporados na composição desse sujeito plural. Nesta longa lista de Luíses deve-se incluir ainda o IX e o XIII. 
Em seu Livro “Orixás e Voduns nos Terreiros de Mina” (1941), o maranhense pai Jorge de Itacy refere-se ao seu encantado como sendo Luís XIII, o rei que era delfim no período da ocupação de São Luís pelos Franceses em 1612. Por sua vez, Mundicarmo Ferretti (2003) no artigo “São Luís e Dom Luís em terreiros da Capital Maranhense” aponta a grande confusão que é feita entre este e Luís IX, canonizado pela Igreja Católica, descrevendo inclusive - com base nos escritos de Itacy e de etnografia realizada em sua casa de santo - a festa de Dom Luís que conta com uma procissão em homenagem ao santo homônimo saída de uma igreja localizada no centro da cidade de São Luís e cortejo real com a presença de rei, rainha, mordomo régio, "mordoma" régia, mordomo mor, "mordoma" mor, aias, vassalos, bandeira real vermelha do império, bandeira real verde dos mordomos régios etc. (Oliveira, 1941).

Mediante a todas as informações que foram passadas só posso concluir que Dom Luís Rei de França é um sujeito plural que passou para o imaginário mais como outro representante do cristianismo do que propriamente como um personagem histórico único.

É preciso notar que ele não possui um dos elementos referidos metaforicamente pelos mineiros na composição de seu panteão que é a soberania portuguesa. Não é um português como já lembrava no começo da década de 70, o casal Leacock. Todavia, não se pode esquecer, que se trata de um rei cristão. Mais do que isso, remetendo ao trabalho de Marc Bloch (1992), faz - ou melhor - fazem parte de uma dinastia - Bourbon - que foi imortalizada por seu poder taumatúrgico.

Mais do que os soberanos portugueses, os reis franceses eram sacralizados pela ascendência predestinada e pelo ritual de unção com os santos óleos. Também vale ressaltar que se tratavam dos descendentes de Clóvis I, o cristianizador da França.

Enquanto indivíduos isolados cada um dos Luíses dá sua parcela de contribuição para o mito. Luís IX é inserido no sincretismo afro-católico que era muito peculiar no Brasil mesmo após a abolição da escravidão. Através de Luís XIII fala-se da história maranhense seja pela menção a figura do rei menino, seja pelo local de encantaria. Para entender essa afirmativa é preciso lembrar que o referido rei era apenas um Delfim no período da colonização do Maranhão. A referência a sua encantaria também remonta a história haja vista que ela se localiza justamente na baia de São Marcos. 


\begin{abstract}
"Em 1612, (os franceses), comandados por Daniel De La Touch, senhor de la Ravardiere, haviam desembarcados numa ilha situada na reentrância da costa formada pelas baias de São Luís e São Marcos, onde convergem os rios Itapucuru e Mearim. Ali os franceses haviam iniciado a construção do Forte de São Luís, em homenagem a Luís XIII, rei da França que deu que deu origem a capital do Maranhão" (Barreto, 1977: 18).
\end{abstract}

E o Luís XVI, guilhotinado na França revolucionária, o que tem a ver com nosso personagem mitológico?

Não há muitas correlações a serem feitas a não ser aquelas que já foram mencionadas anteriormente. No entanto não podemos esquecer as informações contidas em um artigo escrito por Aldrin Moura de Figueiredo em co-autoria com Benedito Nunes (2002), no qual esses intelectuais lembram que os ideais de liberdade, igualdade e fraternidade da França revolucionária do século XVIII chegaram a "raia miúda".

"Alguns estrangeiros se encarregaram de fazer brotar o pensamento radical libertário ou revolucionário, expressões polissêmicas que sobre o ponto de vista da história só ganham sentido relacionadas ao tempo e ao contexto em que foram gestada. Era (...) estrangeira a verdadeira multidão de africanos, oriunda do outro lado do Atlântico, especialmente dos portos de Bissau e Cacheu, e que deu um colorido outro a vida no novo mundo, obra mestra de Pombal e seu irmão com o intuito de reconstruir as bases econômicas da região (...). Foi já nas últimas décadas do século XVIII que as autoridades coloniais ficaram realmente sobressaltadas com as ideias de revolução. O campo era fértil para essa troca de anseios. O mapa amazônico divisava com outras frentes coloniais sobre domínio de Espanha, Inglaterra, Holanda e França. Por isso mesmo temia-se que os cativos de cá entrassem em contato com as ideias perigosas que chegavam da Europa e do Caribe por Ciena. Hoje sabemos que os quilombos do Curuá, nos arredores de Alenquer, Baixo Amazonas, souberam da revolução Francesa de 1789, muito antes que correspondência oficiais chegassem as mãos do Capitão-General Martinho de Souza e Albuquerque, governador do Pará a Época. O mesmo ocorreu com a revolução dos negros do Haiti em 1792 e com a onda de revolta maroons na Jamaica e nas Guianas, entre 1795 e 1797. "As notícias da abolição da escravidão nas colônias francesas e os movimentos de independência no lado espanhol, em especial o da Venezuela, ecoaram entre os escravos de brasileiros com aceno de liberdade." (Nunes \& Figueiredo, 2002: 19) 
Se, como bem lembram esses autores, em outro trecho do mesmo artigo, as gazetas que chegavam da Europa circulavam entre os escravos de Mazagão - nas proximidades de Macapá - insuflando negros e índios, quem pode afirmar que as notícias da decapitação do soberano não correram pelos subúrbios dos centros urbanos do Grão-Pará e Maranhão?

Tentando ensaiar uma resposta volto ao texto:

"No Pará, portanto parece que as "luzes", pelo menos em seu aspecto político, chegaram pela boca dos miúdos, da ralé, do populacho que de todas as maneiras tirava o sono das autoridades da terra. A "gente rude" do Pará, ao contrário do que supunha, Mendonça Furtado, parecia ser muito bem informada." (Nunes \& Figueiredo, 2002: 20)

Não é difícil de imaginar o impacto que a notícia sobre a morte de um rei cristão deve ter causado na sociedade. Para cogitá-lo é necessário não perder de vista que um rei tinha significado muito maior do que um chefe de estado. Se as disputas entre burgueses e nobres não estão relatadas via mito, a cabeça de Maria Antonieta lembra o episódio deste soberano que passou para o imaginário, como todos os outros, através de um evento tão trágico quanto o sumiço de rei Sebastião.

Do Rei Sol permaneceu a empáfias, de um soberano tão poderoso quanto a mais importante estrela do sistema solar, em torno da qual tudo gravita. Talvez a ele, eu possa referir com mais riqueza de detalhes.

Tanto quanto seu antecessor, ascendeu ao trono menino. O poder o cercou em todos os sentidos. Conscientemente construiu a imagem de onipotência. Em função disso financiou diversos artistas que o pintavam a imagem e semelhança de deuses e heróis da mitologia clássica como Apolo e Hercules (Burke, 1994), apresentando-o como onisciente, divino, invencível, dotado de propriedade sagrada. Também incentivou a ciência através da criação da Academie des Sciences e a Academie des Architecture. Todos os seus passos eram representados através da cunhagem de moedas (Burke, 1994). 
Considerando que Luís XIV, definitivamente não foi um rei guerreiro ${ }^{24}$ ou dominador, sua onipotência foi construída pela propaganda e o incentivo às artes que sempre exageravam, dentre outras coisas as vitórias bélicas. Muitas das pinturas encomendadas durante a reforma do palácio de Versalles tinham como tema a guerra contra os holandeses. Não há como negar que Luís XIV era, acima de tudo, um bom propagandista.

Punha-se tão acima do povo que ter acesso ao rei era um ritual de ultrapassagem de barreiras quase inacessível. Afinal ele concentrava em si o poder divino, advindo da sacralidade real e o poder temporal expresso na célebre frase "o Estado sou Eu". Passou sua vida inteira dedicado a construir a imagem sagrada de autoridade. A corte o via como reflexo do cosmo (Burke, 1994).

Foi essa a imagem reproduzida nas pinturas, esculturas em bronze, pedra, tapeçaria, esmalte madeira. Geralmente estátuas em tamanho natural, espalhadas pela França inteira. A oralidade também cumpriu com esse papel através de sermões, versos, discursos. Toda vida do rei era marcada por rituais de marketing a (Burke, 1994) a exemplo de seu casamento, do rito de toque das escrófulas e, posteriormente até, seu funeral. A entrada do rei nas cidades seguia o modelo do triunfo romano. Para isso foram construídos arcos.

Suas representações enfatizavam-no ora como um interessado pela arte, ora como um amante da ciência, ora como um valente montado de cavalos quase indomáveis. Todos os seus feitos foram registrados. Pintores estavam sempre presentes em suas comitivas bélicas, para sagrá-lo vencedor em qualquer circunstância.

Como era característico do poder sagrado dos reis, o Rei Sol era considerado um predestinado. Tratavam-no como um messias desde muito antes de seu nascimento. Todos os passos da gestação foram festejados. O cancioneiro popular o classificava de o enviado de Deus (Burke, 1994).

\footnotetext{
${ }^{24}$ Dentre as guerras travadas por Luís XIV destaca-se a Guerra de Devolução - cujo objetivo era impor o domínio francês ao Países Baixos espanhóis - e a Guerra Holandesa. Na primeira o próprio rei e sua corte, que incluía a esposa e as amantes. Vitorioso, o resultado foi comemorado num festival em Versalhes. A academia de pintura também anunciou premiação a quem desenvolvesse melhor o tema "Luís Pacifica a Europa". Na Guerra Holandesa, o rei se fez acompanhar de historiadores, que imortalizaram os feitos reais como o episódio da travessia do Reno, narravam suas dificuldades para vangloriar a superação.

REVISTA RELEGENS THRÉSKEIA - 2018 - UFPR - UEPA
} 
Alguns quadros anexavam o rosto de Luís na figura de Jesus Bom Pastor, outras o associavam ao seu ancestral canonizado, São Luís. Poemas o relacionavam a Carlos Magno. Não se pode esquecer que o encantado afro-brasileiro possui um filho com nome Carlos. O ápice da identificação do rei com o santo foi quando o mesmo criou a Ordem de São Luís, em 1693. Tal comparação foi institucionalizada na medida em que a festa do referido santo, realizada a 25 de agosto, passou a ser um dia de homenagens ao rei.

O rei possuía outra característica muito cara ao simbolismo afro-brasileiro: era um absolutista, estava acima das leis de seu reino e podia impedir que elas se aplicassem, usou isso ao sufocar o FRONDA. Após a morte do Cardeal Mazarin, em 1661, passou a governar sem primeiro ministro, para não dividir o poder.

Apesar de não se ter notícias de nenhuma perseguição travada por este soberano contra os mouros ${ }^{25}$, sem dúvida foi ele, o grande responsável pela revogação do Edito de Nantes e pelas acirradas perseguições aos protestantes, obrigando cerca de duzentos mil franceses a emigrar para fora da França.

Luís também foi responsável pela expansão do cristianismo na Ásia. Em 1661, ofereceu amizade aos reis da Conchinchina, Tonquim e China, mandando para a região um jesuíta que passou a trabalhar para o Imperador Kang- Hi. Esse contato tinha tanto finalidades de ordem econômica quanto religiosas.

O imaginário mineiro corroborou com a intenção de Luís que visava galgar a imortalidade. E esse personagem, pretensiosamente quase divino, não podia deixar de dar sua contribuição ao panteão afro-brasileiro haja vista que, exceto pela nacionalidade francesa - nação que por vezes representou uma pedra no sapato dos $\operatorname{lusos}^{26}$ - possui todos os atributos necessários para a elevação à categoria de senhor. Era, dentre outras coisas, cristão, centralizador, absolutista e revestido de poder absoluto que não distinguia fronteiras entre o sagrado e o temporal. Não há como negar que o Dom Luís Rei de França tem muito de Rei Sol.

\footnotetext{
${ }^{25}$ Muito pelo contrário Burke (1994) afirma que o rei foi acusado de bajular os otomanos com a finalidade de conquistar Argel e Marrocos. ${ }^{26}$ Cabe ressaltar que apesar das invasões napoleônicas no século XVIII, Portugal não perdeu sua soberania enquanto nação, haja vista que a sede da Coroa foi transportada para o Brasil.

REVISTA RELEGENS THRÉSKEIA - 2018 - UFPR - UEPA
} 
Nesse emaranhado de múltiplas personalidades resta saber o que há de Dom Luís em Xangô, ou a pergunta deveria ser o contrário? Por que essa correlação com o senhor da Justiça, que para o panteão jeje é Dadarro? Há um mito de Xangô que traz informações intrigantes. Prandi (2001) relata que Xangô foi rejeitado por seus súditos e se retirou para uma floresta se enforcando no galho de uma árvore. Como ninguém achou seu corpo foi declarado que o rei tinha virado entidade (2001).

Neste sentido "toda vez que troa o trovão e o relâmpago risca no céu, os sacerdotes de Xangô entoam: O rei não se enforcou, O rei não se enforcou” (Prandi, 2001, 279).

Este mito aproxima o rei enforcado com o rei guilhotinado e dá o mesmo desfecho maravilhoso (Todorov, 2003) para os dois casos: a imortalidade. Resta fazer uma última análise. Por falar no processo de encante de Dom Luís, é útil referir ao mito do navio deste rei que teria aprisionado os turcos e afundado. Dom Luis IX, o santo, foi um herói de cruzada contra os Mouros.

Há também a referência histórica a perseguição aos protestantes, na luta pela expansão do cristianismo. Neste sentido, julgo serem os turcos, usados de forma direta e indireta, como metáfora do não católico. Neste sentido o protestantismo é visto também como infiel que desde o período da reforma, ameaça à soberania de Roma. Essa referência é reproduzida na lembrança feita ao Massacre de São Bartolomeu.

\section{Considerações finais}

Em título de conclusão, gostaria de informar ao leitor que todas as análises aqui realizadas são preliminares. Os dados citados acima apontam para diversos caminhos de análise. Poderia estudar minuciosamente, a relação de parentesco estabelecida entre esses reis e outras entidades nobres ou não nobres. Isso certamente nos traria dados preciosos acerca da divinização das relações sociais e da constituição do povo brasileiro.

Informações detalhadas da história da França, suas dinastias, sua constituição política e econômica poderiam complementar os dados levantados. Talvez nesse material achasse o significado de referências feitas em trechos de músicas e que a primeira vista parecem desconexas.

Está ausente deste artigo a análise do mito dos outros reis. Gostaria de, muito brevemente, destacar três dessas entidades; rei da Turquia, Marquês de Pombal e Dom. Pedro. 
O personagem Rei da Turquia, apesar de ainda não ter sido, devidamente vislumbrado, faz referência à característica $\operatorname{miscível}^{27}$ do povo português e consequentemente do brasileiro que assimilou elementos de muitas outras culturas, embora de maneira desigual. Esse é o caso dos mouros que durante muitos anos ocuparam a Península Ibérica. A presença desse elemento no panteão do "Tambor de Mina” faz refletir no porquê um rei mouro ganhou espaço de sacralidade enquanto a Dinastia Filipina, de procedência espanhola - que dominava o trono lusitano durante o período da fundação de Belém e reconhecimento da Amazônia - foi jogada ao esquecimento, Se ambos representaram crise para a soberania nacional portuguesa, que critérios se utilizou para agregar determinadas personalidades e excluir outras?

Dom Pedro, por sua vez, príncipe herdeiro que se tornou o primeiro rei do Brasil independente, é pouco cultuado. Seria uma referência a desvalorização da autonomia brasileira? Pode-se pensar esse dado como uma das formas de contestar o processo de independência como aconteceu no plano político?

Por enquanto esses questionamentos são apenas uma forma de suscitar discussão, reflexão futura e mostrar ao leitor a riqueza desse campo de análise.

\section{Referências}

BARROS, Flávio Pessoa de. Olubajé. Rio de Janeiro: INTERCON - UERJ, 1999.

A Fogueira de Xangô:O Orixá do Fogo. São Paulo: Ed. Pallas, 2005. BENTO, Maria Aparecida Silva. "Branqueamento e Branquitude no Brasil". In: CARONE, Iray \& BENTES, Maria Aparecida Silva (org.) Psicologia Social do Racismo Estudos sobre Branquitude e Branqueamento no Brasil. Petrópolis: Vozes, 2002.

BLOCH, March. Os Reis Taumaturgos: O Caráter Sobrenatural do Poder Régio na França e Inglaterra. São Paulo: CIA das Letras, 1993.

BRASIL, Mário Lima. Mudanças Musicais Gravadas no Babassuê Gravado em 1938 em Belém $(P a)$. São Paulo: ECA/USP, 2000 (Tese de Doutorado).

BRAUDEL, Fernand. "História e Ciências Sociais. A Longa Duração. In: Debats et Combats. França: Annales E. S.C, 1958.

BURKE, Peter. A Fabricação do Rei: A Construção da Imagem Pública de Luís XIV. Rio de Janeiro: Zahar, 1994.

CACCIATORE, Olga Gudolle. Dicionário de Cultos Afro-Brasileiros. Rio de Janeiro: Forense Universitária, 1977.

CALAZANS, Francisco José. Época Pombalina: Política, Economia e Monarquia. São Paulo: Ática, 1982.

CARNEIRO, Edison. Antologia do Negro Brasileiro. São Paulo: Ediouro, s/d.

${ }^{27}$ Ver Freyre, 1995: 188-262.

REVISTA RELEgENS THRÉSKEIA - $20 I 8$ - UFPR - UEPA 
Religiões Negras, Negros Bantos. Rio de Janeiro: Civilização Brasileira,

2001

Negros Bantos. Rio de Janeiro: Civilização Brasileira S/A, 1993.

Ladinos e Crioulos. Rio de Janeiro: Civilização Brasileira, 1948.

CARONE, Iray \& BENTES, Maria Aparecida Silva (org.) Psicologia Social do Racismo Estudos sobre Branquitude e Branqueamento no Brasil. Petrópolis: Vozes, 2002.

"Branquitude: O Lado Oculto do Discurso sobre o Negro". In:

CARONE, Iray \& BENTES, Maria Aparecida Silva (org.) Psicologia Social do Racismo Estudos sobre Branquitude e Branqueamento no Brasil. Petrópolis: Vozes, 2002.

DA MATTA, Roberto. "A Fábula das Três Raças, ou o Problema do Racismo à Brasileira". In:

Relativizando. Rio de Janeiro: Rocco, 1991.

ELIAS, Norbert. O Processo Civilizador. Vol. 1. Rio de Janeiro: Jorge Zahar, 1993.

. O Processo Civilizador. Vol. 2. Rio de janeiro: Jorge Zahar, 1993b.

Sociedade de Corte. Rio de Janeiro: Jorge Zahar, 2001.

FERRETTI, Sérgio. Repensando o Sincretismo. São Paulo/ São Luís: FAPEMA, 1995.

. Querebetan de Zomadonu: Etnografia da Casa das Minas. São Luís,

EDUFMA, 1983.

FERRETTI, Mundicarmo. Desceu na Guma: O Caboclo no Tambor de Mina. São Luís - A Casa de Fanthi- Ashanti. São Luís: SIOGE, 1993

FIGUEIREDO, Aldrim de Moura. A Cidade dos Encantados: Pajelança, Feitiçaria e Religião

Afro-Brasileira na Amazônia, 1870 - 1950. ( Dissertação de Mestrado). Campinas.

IFCH/UNICAMP, 1996.

FRANKENBERG, Ruth. "A Miragem de uma Branquidade não Marcada”. In: WARE, Vron.

Branquidade: Identidade Branca e Multiculturalismo. Rio de Janeiro: Garamond, 2004.

FRAZER, Sir James. O Ramo de Ouro. Rio de Janeiro: Guanabara, 1982.

FREYRE, Gilberto. Interpretação do Brasil. Rio de Janeiro: José Olyimpio, 1947.

. Ordem e Progresso. Rio de Janeiro: José Olympio, 1962.

Casa Grande e Senzala. Rio de Janeiro: José Olympio, 1968.

Sobrados e Mocambos. Rio de Janeiro: José Olympio, 1977.

FRY, Peter. Para Inglês Ver. Rio de Janeiro: Zahar, 1982.

GEERTZ, Clifford. A Interpretação das Culturas. Rio de Janeiro: Kloogan S/A, 1989.

GINSBURG, Carlo. O Queijo e os Vermes. São Paulo: Companhia das Letras, 1987.

GOFF, Jacques Le. O Imaginário Medieval. São Paulo: Editorial Estampa, 1994.

. “As Mentalidades: Uma História Ambígua". In: História: Novos Objetos. Rio

de Janeiro: F. Alves, 1988.

HAROCHE, Claudine. Da Palavra ao Gesto. Campinas: Papirus, 1998.

LEACOCK, Seth \& LEACOCK, Ruth. Spirits of the Deep: A Study of an Afro-Brasilian Cult.

Nova York: Anchor Book, 1972.

LUCA, Taissa Tavernard de. Devaneios da Memória: A História dos Cultos Afro-Brasileiros em Belém do Pará. (Trabalho de Conclusão de Curso). Belém: UFPA, 1999.

. Revisitando o Tambor das Flores: A Federação Espírita e

Umbandista dos Cultos Afro-Brasileiros do Estado do Pará como Guardiã de uma Tradição.

(Dissertação de Mestrado). Recife: UFPE, 2003.

MARTINS, Oliveira. História de Portugal. Lisboa: Guimaraes, 1951.

MAUSS, Marcel. Sociologia e Antropologia. Vol. 2. São Paulo: EPU, 1974.

MEYER, Marlyse. Caminhos do Imaginário no Brasil. São Paulo: Edusp, 1993.

. Maria Padilha e Toda a Sua Quadrilha. São Paulo: Duas Cidades, 1992.

MURIAS, Manuel. História Breve da Colonização Portuguesa. Portugal: Verbo, 1961.

PRANDI, Reginaldo. Mitologia dos Orixás. São Paulo: Companhia das Letras, 2001. 
\& Souza, Patrícia Ricardo de. "Encantaria de Mina em São Paulo". In:

Encantaria Brasileira: O Livro dos Mestres, Caboclos e Encantados. Rio de Janeiro: Pallas, 2001. PRIORE, Mary del. Festas e Utopias no Brasil Colonial. São Paulo, Brasiliense, 1994.

QUEIRÓS, Maria Isaura Pereira. "Dom Sebastião no Brasil”. In: Dossiê Canudos. São Paulo: USP, 1993-1994.

QUERINO, Manuel. A Raça Africana e seus Costumes. São Paulo: Progresso, 1955.

.Costumes Africanos no Brasil. Rio de Janeiro: Civilização Brasileira, 1938.

257

RACHLEFF, Peter. "Branquidade: Seu Lugar na Historiografia da Raça e da Classe nos Estados

Unidos". In: WARE, Vron. Branquidade: Identidade Branca e Multiculturalismo. Rio de Janeiro:

Garamond, 2004.

RAMOS, Arthur. O Negro Brasileiro.: São Paulo: Nacional, 1951.

. As Culturas Negras. Rio de Janeiro: Guanabara, s/d.

. As Culturas Negras no Novo Mundo. São Paulo: Editora Nacional, 1979.

. O Folclore Negro no Brasil. Rio de Janeiro: Casa do Estudante do Brasil, 1935.

. Introdução à Antropologia Brasileira. Rio de Janeiro: Edições da C.E.B, 1943.

RODRIGUES, Raimundo Nina. O Animismo Feitichista dos Negros Baianos. Rio de Janeiro:

Civilização Brasileira, 1935.

Paulo: Nacional, 1938.

As Raças Humanas e a Responsabilidade Penal no Brasil. São

Os Africanos no Brasil. São Paulo: Nacional, 1977.

SARAIVA, José Hermano. História Concisa de Portugal. Porto: Europa-América, 2001.

SOVIK, L. "Aqui Ninguém é Branco". In: WARE, Vron. Branquidade: Identidade Branca e

Multiculturalismo. Rio de Janeiro: Garamond, 2004.

STEYN, Melissa. "Novos Matizes da Branquidade: A Identidade Branca numa África do Sul

Multicultural e Democrática. In: WARE, Vron. Branquidade: Identidade Branca e

Multiculturalismo. Rio de Janeiro: Garamond, 2004.

TODOROV, Tedzan. Introdução a Literatura Fantástica. São Paulo: Perspectiva, 2003.

VERGER, Pierre. “Uma Rainha Mãe de Santo em São Luís”. São Luís: IPES, 1983.

.Notas sobre o Culto aos Orixás e Voduns. São Paulo: Edusp, 2000.

Círculo do Livro, 1985.

Orixás: Deuses Yorubás na África e no Novo Mundo. São Paulo: Corrupio e

VERGOLINO, Anaíza. O Tambor das Flores. (Dissertação de Mestrado). Campinas: UNICAMP, 1976.

"A Semana Santa nos Terreiros: Um Estudo de Sincretismo Religioso em

Belém do Pará". In: Religião e Sociedade. Rio de Janeiro: ISER, 1987.

Modernidade. Belém: MPEG, 1994.

"História Comum, Tempos Diferentes". In: Amazônia e a Crise da

. Religiões Africanas no Pará: Uma Tentativa de Reconstrução Histórica.

Amazônia. Belém: IPAR, Ano 2, No 2, 2000.

. "Os Cultos Afro no Pará". In: FONTES, Edilza Joana (org.). Contando

a História do Pará: Diálogos entre a História e a Antropologia. . Belém: E. Motion, 2003.

"Ponto de Santo: A Música e o Pará"(Encarte de CD). Belém:

SECULT, 2003.

"Um Encontro na Encantaria: Notas sobre a Inauguração do

Monumental Místico Rei Sabá”. In: Pajelanças e Religiões Africanas na Amazônia. Belém:

EDUFPA, 2008.

\& FiGUEIREDO, Napoleão. A Presença Africana na Amazônia

Colonial. Belém: Arquivo Público do Pará: 1990. 
\& BRASIL, Mário Lima. “A Música de Culto Afro-Brasileiro na Amazônia”( Encarte de CD ). Belém: SECULT, s/d.

WARE, Vron. "Introdução: O Poder Duradouro da Branquidade, Um Problema a Solucinar." In: WARE, Vron. Branquidade: Identidade Branca e Multiculturalismo. Rio de Janeiro: Garamond, 2004.

RECEBIDO em 28/12/2018

APROVADO em 15/01/2019 